\title{
高強度コンクリートの構造体中での強度発現性.と調合強度 STRENGTH DEVELOPMENT OF HIGH-STRENGTH CONCRETE IN STRUCTURE AND PROPORTIONING STRENGTH
}

\author{
桝 田佳 寛*, 佐 藤 幸惠**, 友澤, 史紀*** \\ Yoshihiro MASUDA, Sachie SATO and Fuminori TOMOSAWA
}

\begin{abstract}
The temperature rise of the concrete in early age affects on long term strength development of concrete in the structure between the age of 28 and 91 days.

In this study, comparison between the compressive strength of control specimen subjected to standard curing at 28 days and the compressive strength of core specimens taken from structural members was made, and observations methods of evaluating the concrete strength in structure were discussed.

When the maximum temperature of the concrete in the structure exceeds $60^{\circ} \mathrm{C}$, the concrete strength in structure may be.lower than the compressive strength of the 28 days standard curing specimens.
\end{abstract}

Keywords: High-strength concrete, Strength development of concrete in structure, Control specimen, Core specimens, Maximum temperature

高強度コンクリート, 構造体コンクリートの強度発現, 管理用供試体, コア供試体, 最高温度

\section{1. はじめに}

鉄筋コンクリート造建築物の構造安全性を確保するためには、構 造体コンクリートが所定の強度を有していることが必要である。構 造体コンクリートの強度は、構造体から採取したコア供試体の圧縮 強度によって最も良く評価されると考えられるが、常にコア供試体 を採取して構造体コングリートの強度を評価することは困難である。 そのため、通常は構造体から採取したコア供試体の圧縮強度と工事 現場で採取して標隻羡生・現場水中羡生などの養生を行った管理用・ 供試体の圧縮強度の関係を把握しだ上で、管理用供試体を用いて構 造体コンクリートの強度を評価している。また、日本建築学会の建 築工事標準仕様書 5 鉄筋コンクリート工事（以下 JASS5 と略す）で は、設計基準強度が $36 \mathrm{~N} / \mathrm{mm}^{2}$ 以下の通常強度のコンクリートについ て、構造体コンクリートの強度は、現場水中養生した供試体の圧縮 強度で推定できるとして、現場水中荃生供試体と標準養生供試体と の強度発現の差をもとに調合強度式を定めている。

しかし、設計基準強度が $36 \mathrm{~N} / \mathrm{mm}^{2}$ を超える高強度コンクリートに ついては、コア供試体と管理用供試体との関係はまだ十分に明らか にされているとはいえず、工事ごとに実大部材を作製し、コア供試 体と管理用供試体との関係を求めて調合強度および強度管理方法を 定めるとしているのが現状である。

* 宇都宮大学工学部建設学科 教授・工博

** 宇都宮大学大学院工学研究科博士後期課程 大学院生・修士 (工学)

*** 北海道大学工学研究科 教授・工博
本論文は、高強度コンクリートを用いた実大部材から採取したコ ア供試体の圧縮強度のデータを収集し、高強度コンクリートの構造 体における強度発現性や強度分布特性などを明らかにし、管理用供 試体との関係を把握して、調合強度の定め方および強度管理方法を 検討したものである。

\section{2. 検討対象とした資料と施工実鋻の概要}

\section{1 検討対象とした資料}

高強度コンクリートの構造体における強度発現性に関する膨大な 資料が、日本建築センターの高層鉄筋コンクリート造技術指導委員 会 (旧技術検討委員会) に提出された施工実験報告書として残され ている。この技術指導委員会は、過去 51 件の技術指導（技術検討） を完了しており、本論文は 1986 年以降に技術指導委員会に申請され た 46 件のう方、施工実験の報告書で構造体から採取した個々のコア 供試体の採取位置、圧縮強度、調合条件等の諸元がそろっている 41 件の報告書 1) 41)ならびに建設省総合技術開発プロジェクト「鉄筋コ ンクリート造建築物の超軽量・超高層化技術の開発」（略称:NewRC

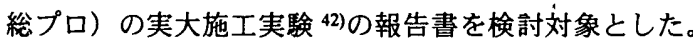

日本建築センターの技術指導委員会に申請された個々の案件にお けるコンクリートの設計基準強度の最大值は $36 \sim 60 \mathrm{~N} / \mathrm{mm}^{2}$ の範囲 
にある。また、NewRC 総プロの実大施工実験では、設計基淮強度 $100 \mathrm{~N} / \mathrm{mm}^{2}$ および $60 \mathrm{~N} / \mathrm{mm}^{2}$ を対象としたが、本論文ではそのうち 60 $\mathrm{N} / \mathrm{mm}^{2}$ のみを対象とする。

施工寒験報告書は、数例を除いてほとんどがコンクリート強度を 従来単位 $\left(\mathrm{kgf} / \mathrm{cm}^{2}\right)$ で表示している。しかし、本論文では、SI 単位 で表示し、 $10 \mathrm{kgf} / \mathrm{cm}^{2}=1 \mathrm{~N} / \mathrm{mm}^{2}$ と換算して解析することとした。

\section{2 施工法の概要}

コンクリートの打込み方法は、垂直部材（柱）と水平部材（梁、 林）とを打ち分ける VH 分離打ち方式と、これらを同日中に打ち込 む一体打ち方式とがあるが、ほとんどが VH 分離打ち方式で、後者 は数例しかない。コンクリートのスランプは、設計基準強度が $60 \mathrm{~N} / \mathrm{mm}^{2}$ と $48 \mathrm{~N} / \mathrm{mm}^{2}$ の一部が $21 \mathrm{~cm}$ であるが、それ以外は $18 \mathrm{~cm}$ で ある。セメントは、最近は高粉末度タイプの低熱ポルトランドセメ ントを用いる例も増えてきたが、今回対象としている施工実験は、 普通ポルトランドセメントを用いている。混和剤は、1987 年までは 流動化㓮を、1988 年以降は高性能 AE 隇水剤を使用している。
鉄筋は、先組みされており、型枠はほとんどシステム型枠である。 VH 分離打ち方式の場合の一般的な施工手順は、柱筋の先組み $\rightarrow$ 柱 筋の建込み・継手施工 $\rightarrow$ 柱型伜の建込み $\rightarrow$ 柱コンクリートの打込み ，梁・床型梊の建込み $\rightarrow$ 梁筋の建込み・床筋の施工 $\rightarrow$ 梁・床コンク リートの打込みであるが、柱コンクリートの打込みと梁・床型枠の 建込みとが逆になる例もある。

\section{3 施工実験の概要}

技術指導委員会に提出された施工実験報告書の施工実験には、施 工実証実験（実大施工実験ということもある）と施工予備実験とが ある。施工実証実験は、試設計建築物の設計基準強度が最大となる 下層階の 1〜2 層・1〜3 スパンを抽出した柱・梁・床からなる架構 を対象として、施工法の概要で述べた手順に従って施工し、その構 造体コンクリート強度、寸法精度、仕上げ状沇、作業性等を確認す るものである。また、施工予備実験は、施工実証実験とほとんど同 じことを予行演習的に行ったものと、柱部材のみを取り出してコン クリートの打込み実験を行ったものなど様々である。

表-1＼cjkstart高強度コンクリート実大柱部材施工実験の概要

\begin{tabular}{|c|c|c|c|c|c|c|c|c|c|c|c|c|c|}
\hline 番号 & 施工実験 & 実験場所 & 実験 & 部材 & 柱部材 & 玮計基準强 & 調合強度 & 水セメ & 単位セメン & 打込み & 最高温度 & \multicolumn{2}{|c|}{ 試嘌体数 } \\
\hline 番号 & 実施期間 & 垁龭場所 & 回数 & 寸法 (mm) & 秷数 & 度 $\left(\mathrm{N} / \mathrm{mm}^{2}\right)$ & $\left(\mathrm{N} / \mathrm{mm}^{2}\right)$ & ント比(x) & 卜量 $\left(\mathrm{kg} / \mathrm{m}^{3}\right)$ & 温度 $\left({ }^{\circ} \mathrm{C}\right)$ & $\left({ }^{\circ} \mathrm{C}\right)$ & 28日 & 91日 \\
\hline 1 & $1986.4 \sim 19865$ & 爱知県豊川市/横浜市 & 2 & 850,900 & 4 & 42.0 & 47.8 & 39.0 & $395 \sim 421$ & $\sim 250$ & 56.0 & 72 & 54 \\
\hline 2 & $19861 \sim 1986.9$ & 千葉県流山市 & 2 & 850 & 4 & 48.0 & 640 & 34.5 & 481 & $80 \sim 280$ & 780 & 51 & 18 \\
\hline 3 & 1986.9 & 横浜市 & 2 & 850,950 & 4 & 36.0 & 44.0 & 40.0 & 438 & $275 \sim 29.0$ & 不明 & 24 & 0 \\
\hline 4 & $1986.10 \sim 1987.2$ & 神奈川県大和市 & 2 & 900 & 4 & 36.0 & 49.0 & 38.0 & $408 \sim 448$ & $150 \sim 220$ & 480 & 48 & 0 \\
\hline 5 & 1987.2 & 埼玉県与野市 & 1 & 900 & 3 & 42.0 & 53.5 & 34.0 & 515 & - & 不明 & 54 & 54 \\
\hline 6 & $1987.1 \sim 1987.9$ & 千幕県東莺飾郡関宿町 & 2 & 900,950 & 6 & 360 & 50.0 & 40.0 & $405 \sim 413$ & $100 \sim 330$ & 63.0 & 84 & 0 \\
\hline 7 & $19864 \sim 1987.10$ & 東京都青梅市 & 3 & 800 & 11 & 36.0 & 48.8 & 380 & $377 \sim 468$ & $175 \sim 31.0$ & 68.0 & 70 & 0 \\
\hline 8 & $1987.4 \sim 198712$ & 神套川県厚木市 & 2 & 900 & 8 & 42.0 & 51.0 & 35.0 & $459 \sim 486$ & $17.0 \sim 240$ & 64.0 & 56 & 36 \\
\hline 9 & $1987.11 \sim 19883$ & 茨城県取手市 & 2 & 900 & 8 & 36.0 & 46.8 & 36.0 & $473 \sim 486$ & $145 \sim 200$ & 45.0 & 99 & 0 \\
\hline 10 & $1987.12 \sim 19884$ & 神奈川県要甲郡爱川町 & 2 & 1000 & 3 & 42.0 & - & 33.0 & 515 & $185 \sim 260$ & 667 & 26 & $\mathbf{0}$ \\
\hline 11 & $1988.8 \sim 1988.11$ & 埼玉県入間郡大井町 & 2 & 850,900 & 5 & 42.0 & 53.5 & 35.0 & $447 \sim 475$ & $170 \sim 32.0$ & 400 & 100 & 0 \\
\hline 12 & $1988.12 \sim 1989.9$ & 茨城県古河市 & 2 & 900 & 3 & 36.0 & 43.0 & 44.7 & $350 \sim 369$ & $13.0 \sim 320$ & 59.7 & 54 & 9 \\
\hline 13 & 1989.9 & 千偞県印旗郡白井町 & 1 & 900 & 3 & 42.0 & - & 36.0 & 464 & $315 \sim 32.0$ & 612 & 72 & 0 \\
\hline 14 & 1989.9 & 大阪市 & 1 & 1000 & 2 & 42.0 & - & 40.0 & 438 & $31.0 \sim 32.5$ & 655 & 24 & 0 \\
\hline 15 & $1988.11 \sim 19902$ & 埼玉県南埼玉郡白岡町 & 5 & $800 \sim 900$ & 14 & 42.0 & 55.8 & 35.5 & $367 \sim 500$ & $155 \sim 220$ & 652 & 89 & 0 \\
\hline 16 & $19899 \sim 1990.7$ & 兵蝻県西宮市 & 4 & 1000 & 8 & 42.0 & 51.8 & 40.0 & $425 \sim 447$ & $110 \sim 330$ & 72.0 & 66 & 20 \\
\hline 17 & $1988.9 \sim 19913$ & 千葉県市川市 & 4 & 850,900 & 16 & 42.0 & 60.0 & 30.5 & $477 \sim 548$ & $15.0 \sim 325$ & 660 & 118 & 104 \\
\hline 18 & $1990.7 \sim 1991.3$ & 千葉県成田市 & 2 & 950 & 6 & 42.0 & - & 33.0 & $457 \sim 485$ & $160 \sim 360$ & 780 & 117 & 0 \\
\hline 19 & $1989.12 \sim 19913$ & 埼玉県入間郡日高町 & 4 & $850 \sim 950$ & 9 & 36.0 & 49.0 & 38.0 & $378 \sim 447$ & $160 \sim 33.0$ & 597 & 112 & 61 \\
\hline 20 & $198912 \sim 1991.3$ & 茨城県猿島郡残和町 & 6 & 850,950 & 18 & 42.0 & 50.4 & 38.0 & $354 \sim 459$ & $10.5 \sim 350$ & 863 & 224 & 76 \\
\hline 21 & $199110 \sim 199111$ & 茨城県つくば市 & 3 & 850 & 10 & 60.0 & - & 27.0 & 611 & $24.0 \sim 270$ & 76.0 & 152 & 116 \\
\hline 22 & 199112 & 栃木県河内郡南河内町 & 1 & 900 & 1 & 48.0 & 64.5 & 32.8 & $439 \sim 517$ & $184 \sim 263$ & 63.0 & 10 & 28 \\
\hline 23 & $1991.1 \sim 1992.1$ & 大阪府門真市 & 4 & 950,970 & 15 & 42.0 & 58.2 & 35.0 & $398 \sim 500$ & $130 \sim 340$ & 58.0 & 176 & 0 \\
\hline 24 & $1991.8 \sim 19923$ & 神奈川県厚木市 & 3 & 900,1000 & 5 & 42.0 & - & 39.5 & $413 \sim 446$ & $170 \sim 27.5$ & 不明 & 66 & 75 \\
\hline 25 & $1991.9 \sim 1992.11$ & 干暴県東暮飾郡関宿町 & 5 & $650 \sim 750$ & 11 & 54.0 & 66.5 & 29.0 & $425 \sim 630$ & $190 \sim 34.0$ & 800 & 178 & 33 \\
\hline 26 & 19933 & 東京都府中市 & 1 & 850 & 4 & 42.0 & 57.0 & 36.0 & 459 & $197 \sim 20.1$ & 530 & 72 & 72 \\
\hline 27 & $19926 \sim 1993.6$ & 干葉県印旗郡印西町 & 2 & 850,900 & 8 & 42.0 & 50.4 & 41.0 & 415 & $28.2 \sim 294$ & 不明 & 88 & 48 \\
\hline 28 & $1991.9 \sim 1993.8$ & 埼玉県大宮市 & 5 & 900 & 15 & 42.0 & 55.4 & 36.0 & $425 \sim 472$ & $175 \sim 35.5$ & 720 & 181 & 92 \\
\hline 29 & $1992.1 \sim 19938$ & 千樭県富津市 & 3 & 900,950 & 11 & 48.0 & 56.8 & 34.0 & $446 \sim 416$ & $16.0 \sim 31.0$ & 730 & 54 & 74 \\
\hline 30 & $1993.2 \sim 19942$ & 横浜市 & 6 & 900,950 & 22 & 42.0 & 63.4 & 35.5 & $314 \sim 532$ & $115 \sim 336$ & 885 & 326 & 322 \\
\hline 31 & $1993.10 \sim 1994.3$ & 神奈川県相摸原市 & 2 & 850 & 3 & 48.0 & 63.0 & 30.0 & $413 \sim 500$ & $18.0 \sim$ & 630 & 36 & 36 \\
\hline 32 & $1993.11 \sim 1994.10$ & 千樭県船橋市 & 2 & 900,950 & 3 & 42.0 & 56.0 & 39.0 & $415 \sim 486$ & $170 \sim 230$ & 62.1 & 46 & 45 \\
\hline 33 & $1994.6 \sim 199411$ & 千葉県印旗郡印西町 & 2 & 850,950 & 8 & 42.0 & 50.4 & 40.5 & $407 \sim 415$ & $19.0 \sim$ & 59.6 & 113 & 89 \\
\hline 34 & 1994.11 & 干萎県署志野市 & 1 & 900 & 2 & 42.0 & 55.8 & 35.5 & 451 & 16.0 & 41.5 & 17 & 18 \\
\hline 35 & $1993.12 \sim 199412$ & 埼玉県上尾市 & 2 & 950 & 5 & 42.0 & 50.4 & 39.0 & 423 & $14.5 \sim 15.2$ & 50.6 & 35 & 44 \\
\hline 36 & $1993.9 \sim 1995.7$ & 干恭県市原市 & 6 & 900,950 & 15 & 42.0 & 62.4 & 36.0 & $378 \sim 472$ & $138 \sim 34.7$ & 78.3 & 363 & 362 \\
\hline 37 & $1994.8 \sim 1995.10$ & 茨城県稆䍩郡美浦村 & 5 & 900,950 & 10 & 48.0 & 69.4 & 36.6 & $447 \sim 531$ & $110 \sim 37.0$ & 892 & 162 & 331 \\
\hline 38 & 1995.10 & 東京都世田谷区 & 1 & 900 & 1 & 42.0 & 56.0 & 39.5 & 418 & 29.1 & 64.4 & 0 & 21 \\
\hline 39 & $1990.8 \sim 199511$ & 大阪府茨木市/東京都東大和市 & 5 & 900,950 & 12 & 42.0 & 57.6 & 31.0 & $389 \sim 545$ & $130 \sim 35.0$ & 830 & 90 & 72 \\
\hline 40 & $1994.10 \sim 1996.5$ & 兵席県三田市 & 3 & $850 \sim 1000$ & 11 & 42.0 & 61.8 & 36.0 & $380 \sim 565$ & $121 \sim 26.8$ & 80.1 & 142 & 141 \\
\hline 41 & $1997.4 \sim 19981$ & 大阪府大東市 & 3 & 900 & 6 & 60.0 & 83.0 & 33.0 & $531 \sim 550$ & $13.3 \sim 31.0$ & 81.0 & 23 & 35 \\
\hline 42 & $1998.4 \sim 19993$ & 千瑟県印旗郡白井町 & 2 & 950 & 5 & 48.0 & 61.7 & 34.5 & $493 \sim 567$ & $19.0 \sim 24.5$ & 93.5 & 57 & 75 \\
\hline
\end{tabular}


施工実験では、柱のコンクリートだけでなく、梁・床のコンクリ 一トも実験しているが、構造体コンクリートの強度性状については、 柱のコンクリートのみを対象とした。また、本論文では、レディー ミクストコンクリートエ場で製造した高強度コンクリートを屋外で 実大柱部材に打ち込んだ場合のみを対象とし、部材の一部分を切り 出して断熱材などで覆ったいわゆる模擬部材と称されるものに打ち 込んだ場合は対象としなかった。なお、実大柱には、鉄筋コンクリ 一ト柱と無筋コンクリート柱とがあるが、両者を対象とした。

検討対象とした施工実験の概要を表-1に示す。実験回数は、コン クリート打込み日ごとに数えた回数であり、調合強度、水セメント 比は最後に行われた施工実証実験における值である。実験回数は、 延べ 120 回、コアを採取して圧縮強度を試験した柱部材総数は 322 本である。コア供試体の圧縮強度試験の，材齢は、1980 年代は材齢 28 日のみ行うという場合が多いが、1990年代は 28 日と 91 日の両方で 試験している例が多い。1 材路に 1 部材から採取したコア供試体の 本数は、最少 2 本から最多 44 本まであり、平均すると 12.5 本であ る。

\section{3. 検討結果と考察}

\section{1 コアの採取方向の影響}

施工実験における柱部材からのコア供試体の採取方向には、部材 軸に治って縦方向に行う場合と部材軸に直行するように横方向に行 う場合とがある。そこで、コアの採取方向が圧縮強度におよぼす影 響 43)を検啥するために、 1 材齢に 1 部材から縦方向、横方向の両方 向から各々複数本のコア供試体を採取しているものを取り上げ、そ れらの圧縮強度の平均值の関係を示したものが図-1である。1 部材 で両方向からコアを採取している例は 12 社、43 部材あった。図-1 より、維方向に採取した方が横方向に採取したものより若干強度が 高い傾向にあるが、大きな差はない。従って、以下の検討ではコア の採取方向に関しては区別しないで取り扱うこととする。

\section{2 構造体中での圧縮強度のばらつき}

1 部材から採取したコア供試体の本数とその圧縮強度の標準偏差 の関係を図-2に示す。図-2から、コア供試体の本数と圧縮強度の標 準偏差はほとんど関係がないことがわかる。

そこで、1 部材から 3 本以上のコアを採取しているものを対象に、
1 部材における圧縮強度の平均値と標準偏差の関係を示すと図-3の ようになる。図-3 から、標準偏差は、王縮強度が $36 \mathrm{~N} / \mathrm{mm}^{2}$ から $80 \mathrm{~N} / \mathrm{mm}^{2}$ の範囲において、圧縮強度とほとんど無関倸に $1 \mathrm{~N} / \mathrm{mm}^{2}$ か ら $8 \mathrm{~N} / \mathrm{mm}^{2}$ の範囲に分布していることがわかる。さらに、この標準 偏差を変動係数で示すと、平均では 6〜7\%、最大では 11〜12\%とな る。

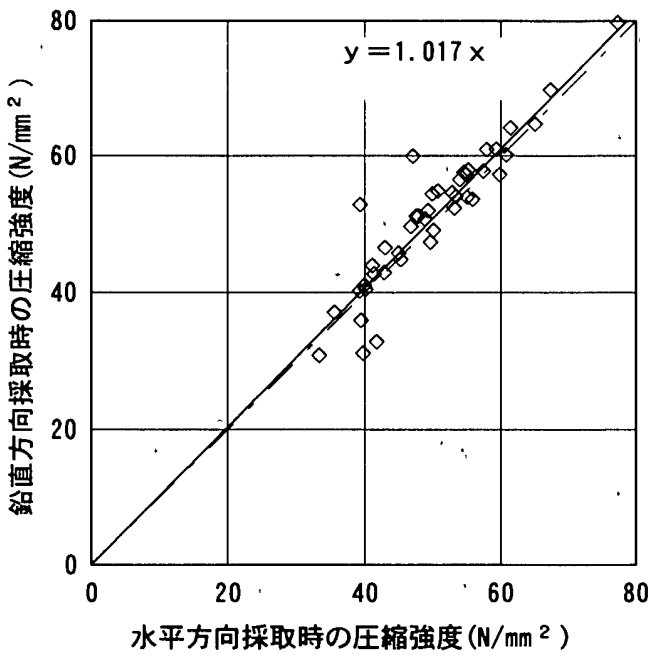

図-1コア採取方向の影暗

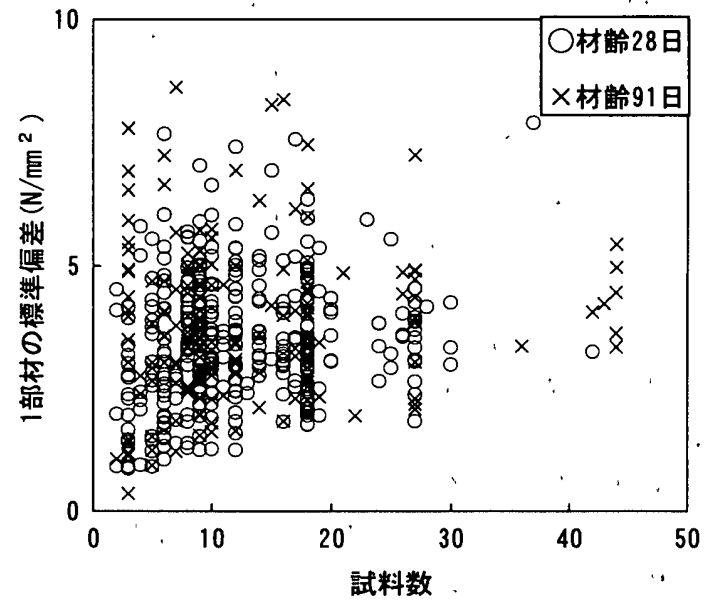

図-2 コア供試体数と標準偏差の関係

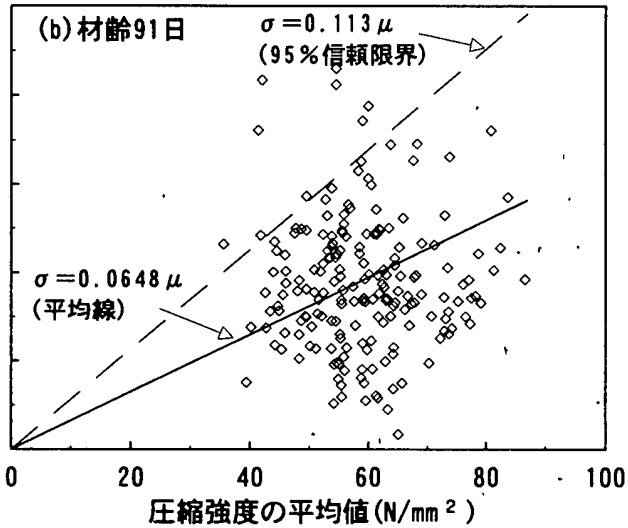

図-3＼cjkstart權造体コンクリートの圧樎強度の平均值と標準偏差 
3. 3 搆造体に おける強度発現

同じ部材から採 取したコア供試体 の材齡 28 日圧縮 強度の平均值之材 齢 91 日圧縮強度 の平均値の関係を 図-4に示す。図-4 から、構造体にお いては材糩 28 日 から材齡 91 日に かけて圧縮強度は およそ1.12倍に增 加することがわか る。 次に、材齢 91
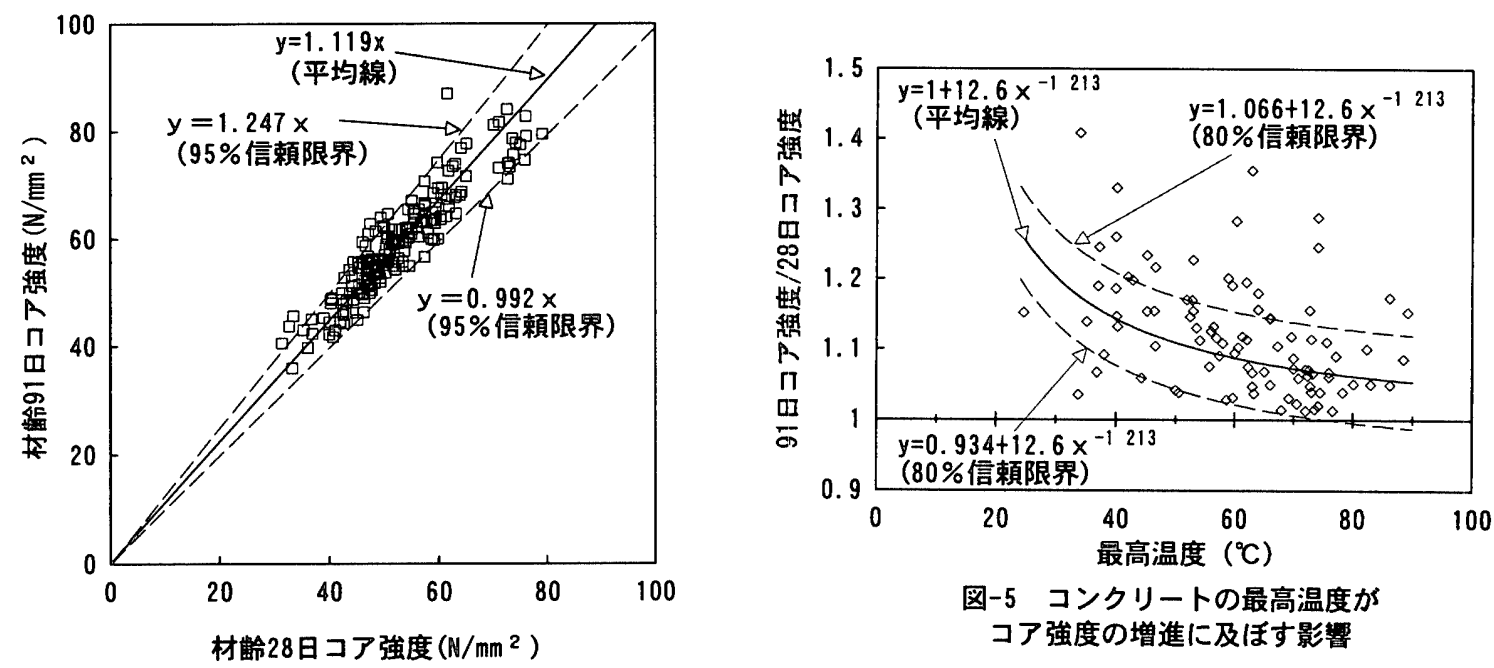

図-5 コンクリートの最高温度が コア強度の增進に及ぼす影幚

図-4 同一部材から採取したコア供試体の材秢28日の 圧缩強度の平均值と材秢91日の圧縮強度の平均値の関係

日圧縮強度の材齢 28 日圧縮強 度に対する割合に及ぼす部材の コンクリートの最高温度の影響 を図-5に示す。図-5から、コン クリートの最高温度が高くなる

と、材齢 91 日の圧縮強度の材齢 28 日の圧縮強度に対する割合 は小さくなり、最高温度が約 $75^{\circ}$ Cになると約 $20 \%$ の確率で 材龄 28 日からの圧縮強度の増 加がみられなくなるものが現れ ることがうかがえる。

\section{4 管理用供試体の圧縮強}

度とコア供試体の圧縮強度 の関係
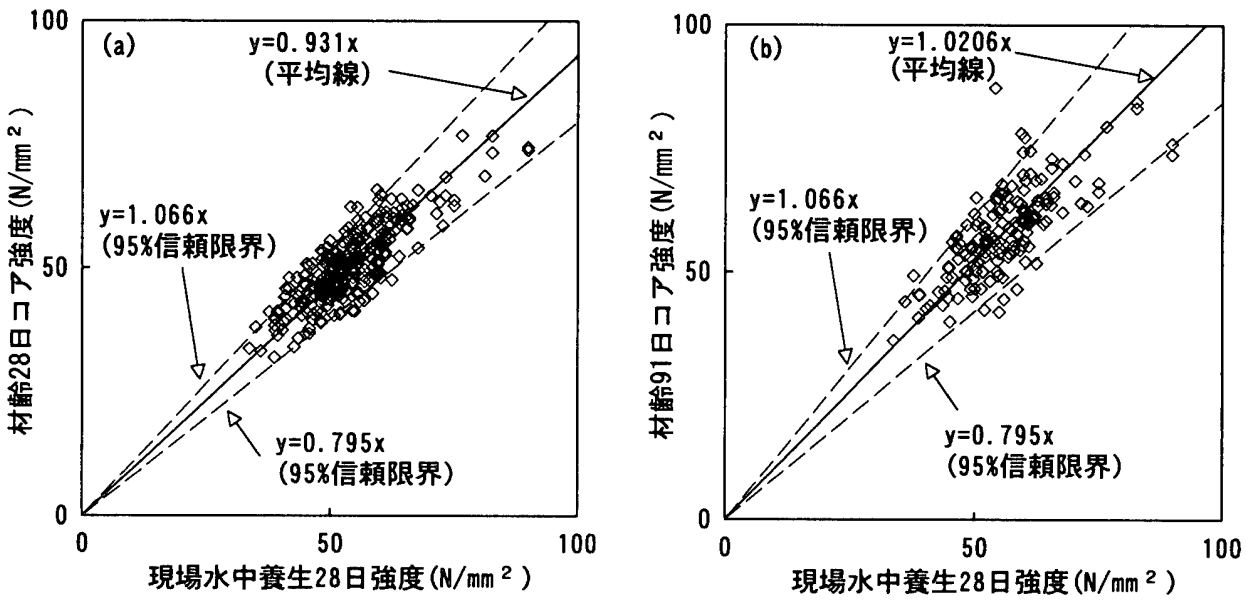

図-6 現場水中等生供試体28日圧縮強度と コア供試体28日および91日圧縮強度の関係

通常強度のコンクリートでは、

構造体コンクリートの強度は現場水中養生または現場封かん養生し た供試体の圧縮強度で推定することとしている。そこで、今回の対 象としている高強度コンクリートについても現場水中養生供試体の 材龄 28 日圧縮強度とコア供試体の材齢 28 日および 91 日圧縮強度の 関倸をみると図-6 のようになり、現場封かん養生供試体の材齢 91 日圧縮強度とコア供試体の材齢 91 日圧縮強度の関係は図-7 のよう になる。現場水中養生供試体の材歯 28 日圧縮強度に対するコア供試 体の圧縮強度は、材制 28 日では平均して $93 \%$ 程度であるが、材歯 91 日では平均して $102 \%$ 程度に增大している。また、材齢 91 日の現 場封かん養生供試体の圧縮強度に対するコア供試体の圧縮強度は、 平均して 97\%程度である。これらの関係は、通常強度のコンクリー トの場合と大差はないようである。

摽淮盖生供試体と現場水中盖生供試体および現場封かん養生供試 体との圧縮強度の差と平均気温との関係を図-8、図-9に示す。平均 気温は、施工実験場所での気温のデータが残されていないため、理 科年表の東京、名古屋および大阪の平均気温のデー夕を用いた。図 -8、図-9 から、設計基準強度が $36 \mathrm{~N} / \mathrm{mm}^{2}$ を越える高強度コンクリー 


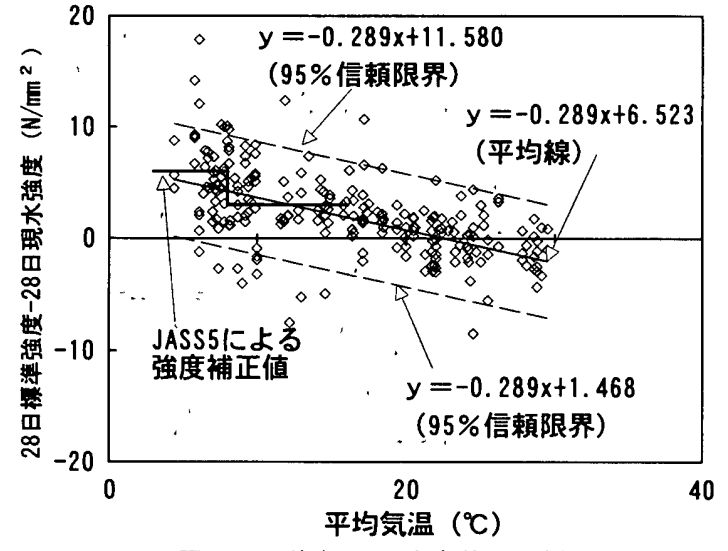

図-8 平均気温と強度差の関係

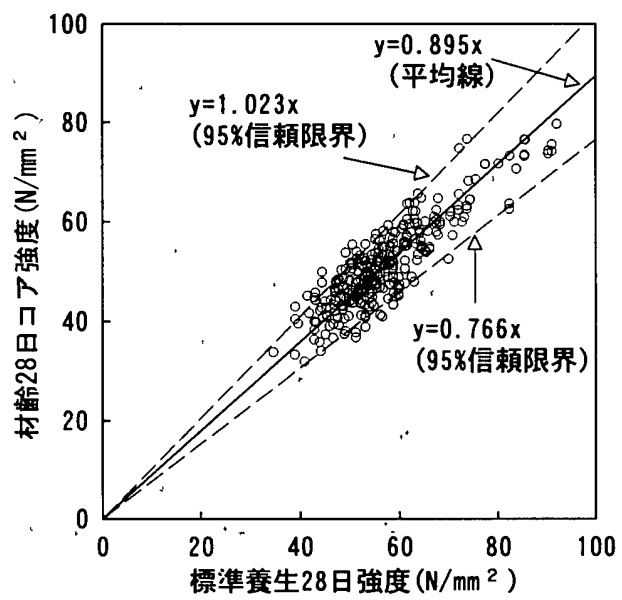

図-10 標準28日強度に対する28日および91日コア供試体強度

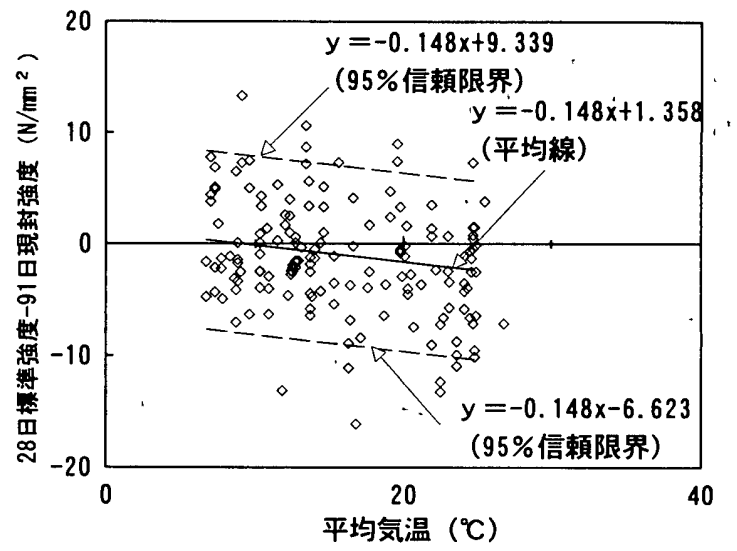

図-9 平均気温と強度差の関係

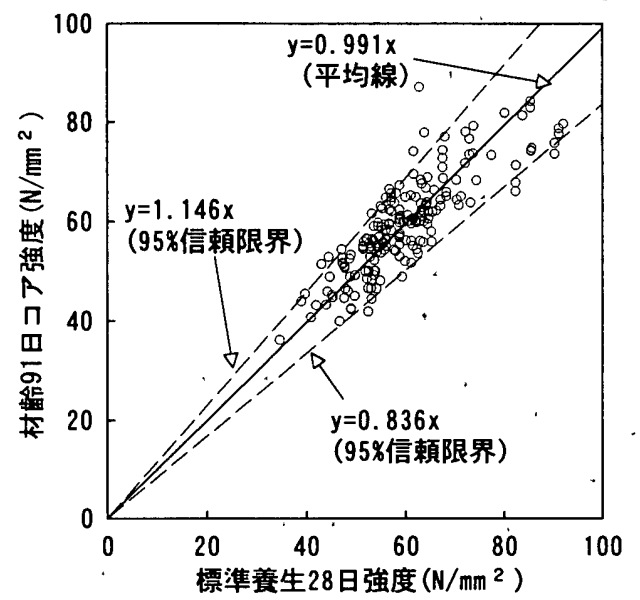

トにおいても、平均的にはJASS5 における予想平均気温による強度 補正值とほほ同じような値になっているが、ばらつきはかなり大き い。本論文で対象とした柱部材のほとんどは、断面寸法が $80 \times 80$ $100 \times 100 \mathrm{~cm}$ であり、マスコンクリートである。そのため、平均気温 ではなく、平均養生温度（コンクリート温度）に基づく強度補正值 を設定した方が良いと考えられる。

高強度コンクリートは、単位セメント量が多く、構造体コンクリ 一トは初期材齢に高温履歴を受け、現場水中盖生や現場封かん盖生 した供試体とは異なる温度履歴となる。そのため、現場水中養生や 現場封かん養生した供試体で構造体コンクリートの強度を評価する ことは合理的でないと考えられる。

そこで、構造体コンクリートの強度を標準養生供試体の圧縮強度、 いわゆるポテンシャルの強度をもとに評価することとする。標準盖 生供試体の材齢 28 日圧縮強度に対するコア供試体の圧縮強度の関 係を示すと図-10のようになり、コア供試体の圧縮強度は材路 28 日 では平均して標準金生供試体の材路 28 日圧縮強度の約 $90 \%$ あ゙る が、材羚 91 日では平均して 99\%程度に増加し、ほとんど標準養生 供試体の材齢 28 日圧縮強度と同じ值になる。

次に、コンクリートの最高温度と標準養生供試体の 28 日圧縮強度 に対するコア供試体の材齢 91 日圧縮強度の比の関係を示すと図-11 のようになる。図-11 から、コンクリートの最高温度が $1{ }^{\circ} \mathrm{C}$ 高くなる

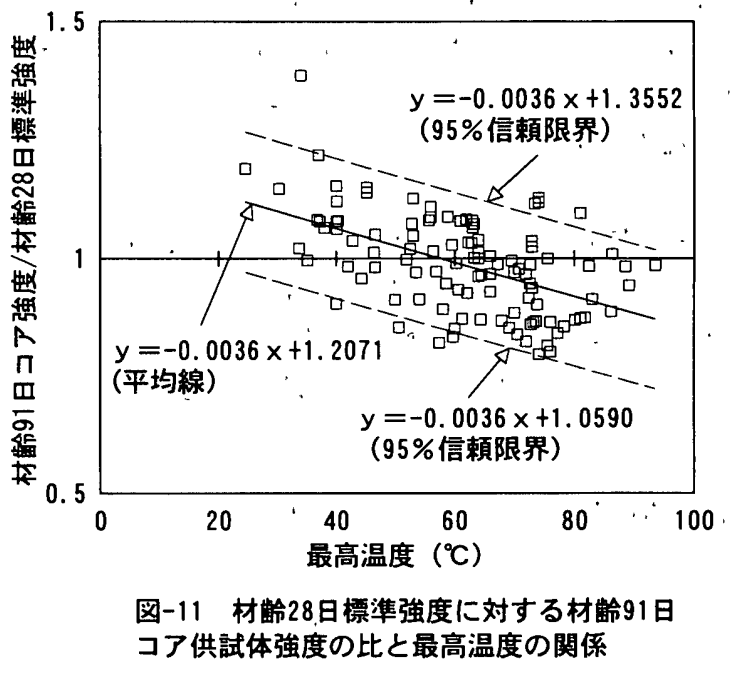

ごとに、コア供試体の材齢 91 日圧縮強度の標準養生供試体の材齢 28 日の圧縮強度に对する割合は 0.0036 だけ小さくなり、最高温度が 約 $60^{\circ} \mathrm{C}$ になるとコア供試体の材齢 91 日圧縮強度は半数の場合にポ テンシャルの強度である標準盖生供試体の材齢 28 日の圧縮強度に

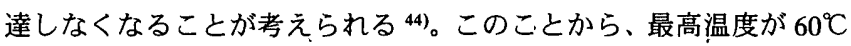




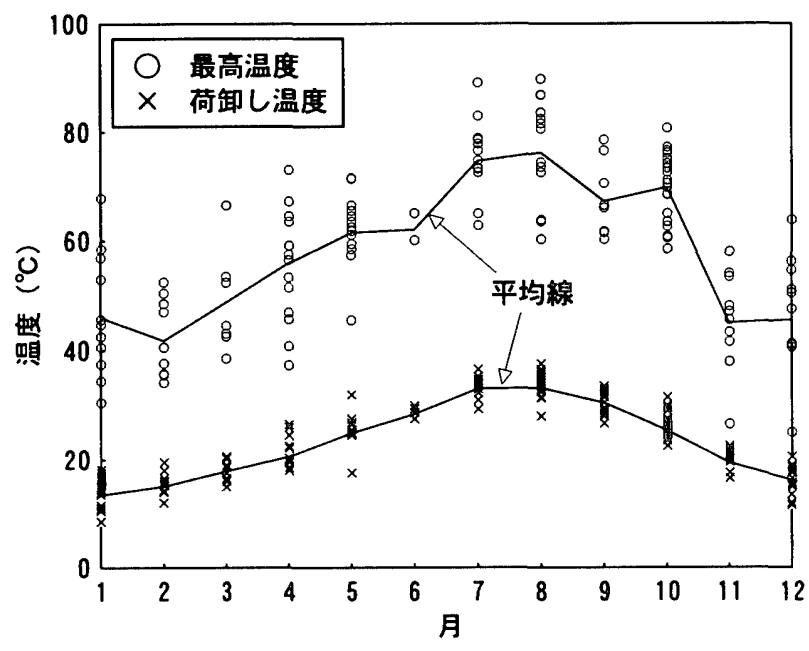

図-12 荷卸し温度と最高温度

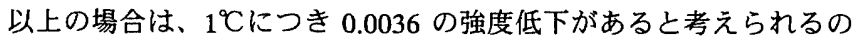
で、調合強度は(1)式による割增しをするのが良いと考えられる。

$$
\begin{aligned}
\alpha_{T}=1+0.0036 \times & \left(T_{\max }-60\right) \\
\text { ただし、 } \alpha_{\mathrm{T}} & : \text { 調合強度の割增し倸数 } \\
\mathrm{Tmax} & : \text { コンクリートの最高温度 }\left({ }^{\circ} \mathrm{C}\right)
\end{aligned}
$$

以上のことをまとめると、構造体コンクリートの強度を材齢 91 日の コア供試体の圧縮強度で定義した場合、コンクリートの最高温度が $60^{\circ} \mathrm{C}$ 以下の場合は、ポテンシャルの強度である標準養生供試体の材 路 28 日圧縮強度とみなせば良く、最高温度が $60^{\circ} \mathrm{C}$ 以上の場合は、 (1)式の割增し係数 $\alpha_{\mathrm{T}}$ で標準養生供試体の材齢 28 日圧縮強度を除し た値とみなせば良いと考えられる。

\section{5 搆造体コンクリートの温度上昇量}

コンクリートは、初期材齢に高温履歴を受けると長期材齢におけ る強度発現の増加が停滞することが知られている。図-12 は、月別 のコンクリートの打込み温度または荷卸し温度と部材の最高温度を 示したものであるが、打込み温度が高いとコンクリート温度上昇量 も大きくなる傾向にあることがわかる。構造体コンクリートの温度 上昇に影響を及ぼす要因として、単位セメント量、部材寸法の他に コンクリート打込み温度が考えられる。そこで、これらの要因を説 明変数とし、構造体コンクリートの最高温度を従属変数として重回 帰分析を行うと表-2にようになり、構造体コンクリートの最高温度 は、(2)式で表される。また、(2)式で得られる推定值と実測値とを比 較すると図-13 のようになり、比較的良く推定できることがわかる。

$$
T_{\max }=0.058 \cdot C+0.043 \cdot D+1.61 \cdot T_{0}-44.2
$$

$$
\begin{array}{cll}
\text { ここで } & \mathrm{T}_{\max }: \text { コンクリート最高温度 }\left({ }^{\circ} \mathrm{C}\right) \\
\mathrm{C} & : \text { 単位セメント量 }\left(\mathrm{kg} / \mathrm{m}^{3}\right) \\
\mathrm{D} & : \text { 柱部材寸法 }(\mathrm{mm}) \\
& \mathrm{T}_{0} & : \text { コンクリート打込み温度 }\left({ }^{\mathrm{C}} \mathrm{C}\right)
\end{array}
$$

\begin{tabular}{|c|c|c|c|}
\hline 説明変数 & 偏回㷌係数 & 標準誤差 & $\mathrm{t}$ 值 \\
\hline 切片 & -44.2 & 12.94 & -3.42 \\
\hline C & 0.058 & 0.0082 & 7.03 \\
\hline D & 0.043 & 0.0119 & 3.64 \\
\hline $\mathrm{T}_{0}$ & 1.61 & 0.920 & 17.46 \\
\hline \multicolumn{2}{|c|}{ 重相関係数（R） } & \multicolumn{2}{|c|}{.0 .845} \\
\hline \multicolumn{2}{|c|}{ 寄与率（R²） } & \multicolumn{2}{|c|}{.0 .713} \\
\hline \multirow{2}{*}{\multicolumn{2}{|c|}{$\begin{array}{l}\text { 自由度調整済寄与率 } \\
\text { 標淮誤差 }\end{array}$}} & \multicolumn{2}{|l|}{0.708} \\
\hline & & \multirow{2}{*}{\multicolumn{2}{|c|}{$\begin{array}{l}8.193 \\
.148\end{array}$}} \\
\hline \multicolumn{2}{|c|}{ 観測数 } & & \\
\hline
\end{tabular}

\section{6 標準養生供試体の 28 日压缩強度の变動}

一連の施工赛験では、柱のコンクリートの打込みに際しては $2 \sim 4$ 台の運搬車のコンクリートを、また、梁・林のコンクリートの打込 みに際しては 3〜10 数台の運搬車のコンクリートを用いて実験して いる。また、土間コンクリートの打込みに際しても同じ調合の数台
表-2 温度上昇に及ほす各種要因分

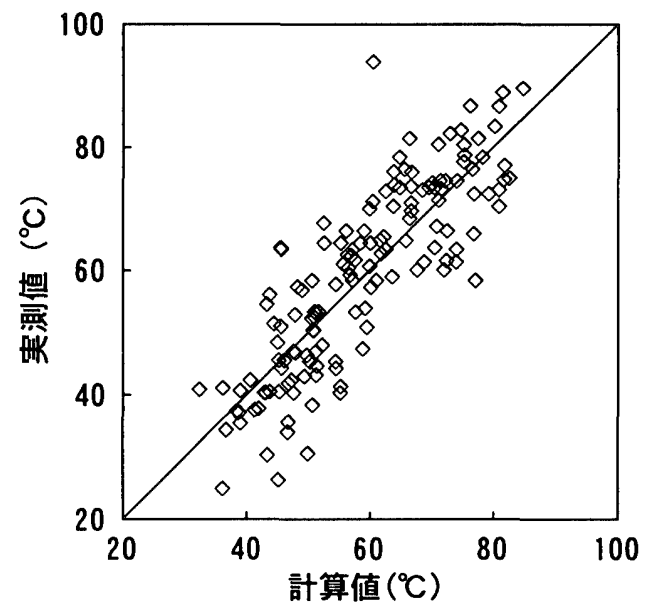

図-13 最高温度の計算値と実測值の関係

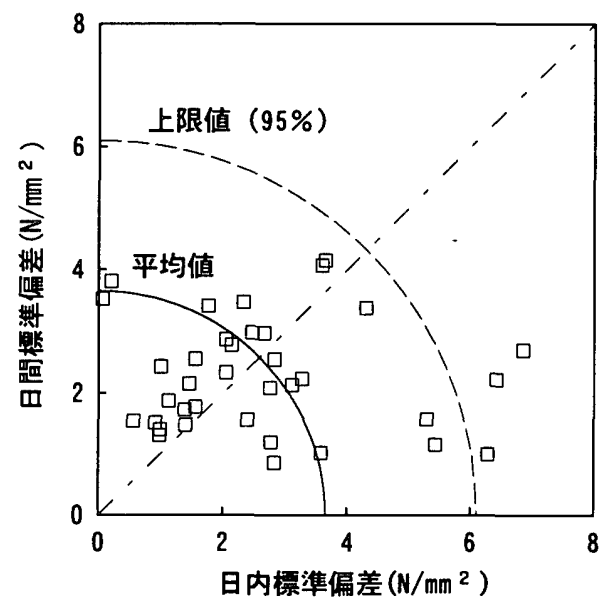

図-14 日内㮀準偏差と日間標準偏差の関係

の運搬車のコンクリートを用いている例もある。そこで、これらの テータを用い、日内変動、日間変動および全変動を調べることとし た。日内変動は 1 運搬車から採取した標準羑生供試体の材齡 28 日圧 縮強度の平均值を 1 テータとし、2 4 台分の標準偏差 $\sigma_{\mathrm{a}}$ から求め た。日間変動は、柱コンクリートの打込み日の圧縮強度の平均値、 梁・床コンクリートの打込み日の圧縮強度の平均値および土間コン クリートの打込みがある場合は、その圧縮強度の平均值を各々 1 テ 一タとしてそれらの標準偏差 $\sigma_{\text {。 }}$ から求めた。図-14 は日内標準偏差 と日間標準偏差の関係を示したものであるが、これら両者にはほと んど相関閔係はみられない。図-15 は、压縮強度の平均値と標準偏 

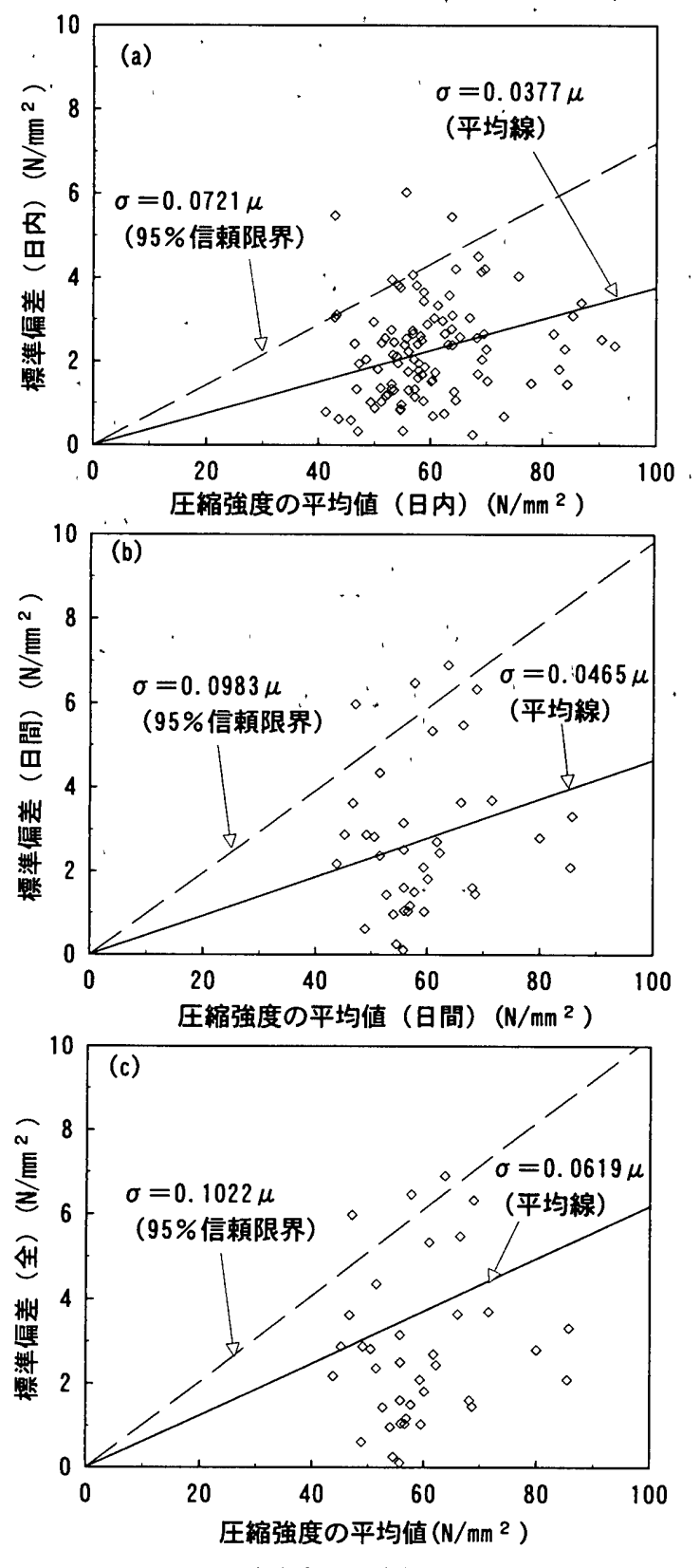

図-15 圧樎強度の平均值と標準偏差の関係

差の関係を示したものである。日内標準偏差は圧縮強度の平均値に 対して平均で約 $3.8 \%$ 、最大で約 $7.2 \%$ 、日間変動は、平均で約 $4.7 \%$ 、 最大で $9.8 \%$ となった。

全変動の $\sigma_{\mathrm{T}}{ }^{2}$ は、日内変動 $\sigma_{\mathrm{a}}{ }^{2}$ と日間変動 $\sigma_{\mathrm{b}}{ }^{2}$ の和として求められ 全標準偏差は平均で約 $6.2 \%$ 、最大で約 $10.2 \%$ である。これらの值 は既往の調查 ${ }^{45)}$ と比較的一致している。

以上のことから、高強度コンクリートの標準養生供試体の材齢 28 日圧縮強度の標準偏差（全変動）は、最大で圧縮強度の平均値の約 $10 \%$ とて良いと考えられる。

\section{4. 結論}

本論文は、普通ポルトランドセメントを用いた設計基準強度が 36 $\sim 60 \mathrm{~N} / \mathrm{mm}^{2}$ の高強度コンクリートの実大柱部材から採取したコア供
試体の圧縮強度のデータを収集し、高強度コンクリートの構造体に おける強度発現性、調合強度の定め方などを検討したものである。 その結果は次のようにまとめられる。

（1）コアの採取方向と圧縮強度との関係は、鈶直方向に採取した 方が水平方向に採取したものより若干高い傾向にあるが、大き な差はない。

（2）1 部材から採取したコア供試体の圧縮強度の標準偏差は、 $1 \mathrm{~N} / \mathrm{mm}^{2}$ から $8 \mathrm{~N} / \mathrm{mm}^{2}$ の範囲に分布し、変動係数で表すと平均で 6〜7\%、最犬で 11〜 12\%となる。

（3）材齢 28 日から91 日にかけて、構造体における圧縮強度は平 均して約 1.12 倍に増大するが、コンクリートの最高温度が高く なるごとにその割合は小さくなり、最高温度が約 $75^{\circ} \mathrm{C}$ にると その約 20\%に強度の増進がなくなる。

(4) 標準養生供試体の材齢 28 日圧縮強度に対するコア供試体の材 齢 91 日圧縮強度の比は、コシクリートの最高温度が $60^{\circ} \mathrm{C}$ にな ると半数の場合に 1 以下になる。このことから、最高温度が $60^{\circ} \mathrm{C}$ 以上になると、調合強度は $1+0.0036\left(\mathrm{~T}_{\max }-60\right)$ 、(ただし $\mathrm{T}_{\max }$ : コンクリートの最高温度）の割增を必要とする。

（5）構造体コンクリートの温度上昇量は、単位セメント量、部材 寸法およびコンクリート打込み温度の関数として(2)式で良く 表される。

（6）標準羑生供試体の 28 日圧縮強度の標準偏差は、最大で圧縮強 度の平均値の約 $10 \%$ である。

\section{謝辞}

本解析の実施に際して貴重なデータの使用を許可いただきました三 井建設、フジ夕、熊谷組、間組、西松建設、飛島建設、銭高組、前 田建設工業、日本国土開発、佐藤工業、安藤建設、東海興業、不動 建設、奥村組、淺沼組、新井組、五洋建設、鉄建建設、日産建設、 地崎工業、住友建設、松村組、長谷エコーポレーション、三菱建設、 青木建設、藤木工務店、北野建設、新日本製鐵、東急建設・東急工 建、東鉄工業 - 大都工業、多田建設、冨士工、共立建設、勝村建設 日東建設・日特建設、日本建設、白石建設 - 松尾工務店、東洋建設、 大日本土木、大末建設、大鉄工業、大木建設の関係各位に感謝いた します。また、本解析に際して協力いただきました宇都宮大学卒論 生細田竜子さんに謝意を表します。

\section{参考文献}

1)并建設 : 三井建設高層 RC システム (MRC-40) 実大施工実験報告 書, 198611

2) フシタ : FHRC システム 実大施工実駼報告書, 198611

3) 熊谷組 : 熊谷組超高層 RC 構法 実大施工実験報告書, 1986.11

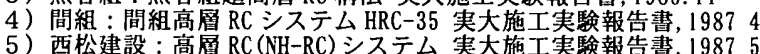

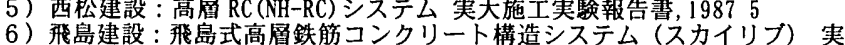
飛鳥建設: 飛島式高層鉄筋

7) 銭高組: ZRC (超高首 RC 集合住宅) システム 実大施工実験報告書, 1987.12 [注] 銭高組技報 No 13,1989

8 ）前田建設工業：前田建設工業高層 RC システム(MARC システム) 実大施工 実駼報告書, 19886 (注) 技術研究所報 Vol 29-2,1988

9 ）日本国土開発：日本国土開発高層 RC システム(SHRC システム) 実大施工

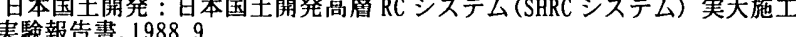

0) 佐滕工業: 佐藤工業高首 RC システム (SHRC システム) 実大施工実験報告

11) 書, 19894 藤建設: ARCS-25 安藤超高屏 RC システム実大施工実験報告書, 1989.4

12) 東海臖業: 高層鉄筋コシクリート構造システム (TK-HRC 30) 実大施工実駼 報告書

13）不動建設：FIT-HRPC(不動高層 RC システム) 実大施工実験報告書

14）奥村組：高首鉄筋コンクリート構造システム(SKYRC-30 システム) 実大 施工実駼報告畫 1989.11

15) 淺沼組：浅沼超高層 RC 住宅構法 (A-HRC30) 実大施工実験報告書, 1990.4 
【注〕檥沼組技術研究所報 NNo 2, 1990

16）新并組: 新并組超高層 RC 造建造物設計施エシステム (AHRC-35) 実大施工 実験報告書, 1990.12

17）五洋建設：五洋建設超高層 RC 構法(PHRC システム) 実大施工実験報告 書, 1991.5

[注]技術研究所年報 Vol 21,1991

18）鉄建建設: 鉄建式高層鉄筋コシクリート造システム(THR-30) 実大施工実 赫告書, 1991.5

[注] 92 研究発表概要 特集号

19）日産建設：日産建設超高層 RC 構法(NRC-25 システム) 実大施工実験報告 書, 19918

20）地崎工業：地崎工業超高首 RC 構法（CHRC システム）実大施工実験報告 荘, 1992.1

21）集友建設：住友式高層 RC 造建築システム(ShiS-RC30) 実大施工実験報告 書, 1992.5

22）菘村組：松村式高㞒鉄筋コンクリート造構法(MHR-100 システム) 実大施 工実験報告書, 19925

23）長谷エコーボレーション：長谷工高層鉄筋コンクリート造設計・施工シ ステ公実大施工実駼報告書, 1992.7

[注] 長谷工技報 No.9 別冊

24) 三菱建設: 三菱建設高層鉄餀コンクリート造構法 (MC-HRPC25 システム) 実 大施工実験報告書, 19933

5）青条建設: 青木式高層 RC 集合住宅構法 (AHS 構法) 実大施工実験報告 書, 1993.5

26）藤木工務店：藤木工務店高層鉄筋コンクリート造(FKRC システム) 実大 施工実駼報告書, 199312

27）北野建設：北野建設高盾 RC 造建築システム(KTN-RC システム) 実大施工 実駼報告畫, $1993 \quad 12$

28）新日本製鐵：新日鐵超高首 RC 構法(NS35 システム) 実大施工実駼報告 書, 1993.12

29）東急建設：東急建設・東急工建高首 PRC 構法(THRPC システム) 実大施工 実駼報告書, 1994.7
30）東鉄工業・大都工業 : 東鉄・大都高層鉄筋コンクリート構法 (TD-KRC30 システム) 実大施工䒠駼報告書, 19949

31）多田建設 : 多田建設高層 RC 造建筑構法(TKRC-30 建築システム) 䒠大施 工実験郝告蕃, 1995.4

32）冨士工：目士工式高層鉄筋コンクリート構法(HUJ IKO-HRC30 システム) 実

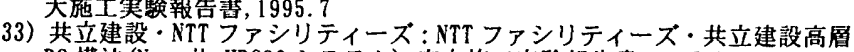
RC 構法 (N ・共. HRC30 システム) 実大施工実験報告書, 1995.7

34) 勝村建設・日東建設・日特建設：KNN 高首鉄筋コンクリート構法 (KNN-HRC システム）実大施工実験報告書，199510

35）日本建設 : 日本建設高層鉄筋コンクリート構法(N-HRC システム) 実大施

36) 白石建设・松尾工務店：白石・松尾高居鉄解コンクリート構法 (S\&M KRC-27 システム) 実大施工実験報告書, 19966

37) 東洋建設: 東洋建設高層 RC 構法 (TONERS-31) 実大施工㬰験報告書, 19966 （注）東洋建設技術研究報告特集号 1996

38）大日本士木：大日本土木高層鉄筋コンクリート造システム $(\mathrm{Hb}-\mathrm{R})$ 実大 施工実験報告書, 1996 . ?

39）大末建設：大末建設高層鉄筋コンクリート造構法（Dh I-RC システム）実 大施工実験報告書, 19972

40）大鉄工業・ジェ仍-师西日本コンサルタンッ：大鉄・J R西日本 G 㮖造 RC 構法 (D\&J-HRC システム) 実大施工実験報告書, 1998.6

41）大貄設：大木建設高首 RC 構法 $(0 \mathrm{H}-\mathrm{RC} 30$ システム) 実大施工実験報告 書 1999.8

42）间本公夫，上村克郎，友澤史紀，清水昭之，桝田佳寛，中根潡，平賀友晃，他: NewRC 実大施工実验 その1 その 31 , 日本建築学会学術講演梗概集 $\mathrm{A}$ (北陸) pp. $299-360,1992.8$

43）構造体コンクリート強度研究委員会 : 構造体コンクリート強度に関する 研究の動向と問題点, 日本建筑学会, 1987.11

44）松本雅之拁田佳寛，阿部道彦：高強度コンクリートを用いた權造体コン クリートの強度管理方法に関する考察, 日本建築学会学術煐演梗概集 A (東北) pp 837-838, 19919

45）福士晁, 横山昌寛: 高強度コンクリートの品質変動特性に関する実態調査, セメント・コンクリート No.538, pp. 25-33,1991.12

（1999年12月10日原稿受理，2000年 6 月 12 日採用决定） 